\title{
Analysis of Longwall Salvage Operations in JSC SUEK-Kuzbass Underground Mines
}

\author{
Inna Yermakova ${ }^{1, *}$, and Vyacheslav Fedusov ${ }^{2}$ \\ ${ }^{1}$ T.F. Gorbachev Kuzbass State Technical University, 650000 Kemerovo, Russian Federation \\ ${ }^{2}$ JSC SUEK-Kuzbass, 1 Vasilieva, 652507, Leninsk-Kuznetsky, Russia
}

\begin{abstract}
The longwall coal mining method is the most productive mining method. However, the salvage operations which include the formation of the salvage chamber and the salvage of longwall face equipment require improvement. In 2011-2017, the time spent for salvage operations in SUEK-Kuzbass mines exceeded the standard time by more than 900 days. It has been established that the longwall face width from 230 to $300 \mathrm{~m}$ has no effect on the duration of salvage operations.
\end{abstract}

\section{Introduction}

The underground mines of JSC SUEK-Kuzbass use the longwall mining system for extraction of coal seams, which is the most productive mining system. They use modern mining equipment, the length of a longwall panel can be as high as 2,500 $\mathrm{m}$ while the face can be up to $400 \mathrm{~m}$ wide, and the monthly production rate can be up to 500,000 tonnes.

However, when assessing the productivity of a longwall and a mine as a whole, it should be noted that the operation of longwall face equipment is preceded by the installation of this equipment, and at the end of longwall operation the face equipment has to be salvaged for operation of the next panel. Our experience has proven that the salvage of longwall face equipment is often associated with difficulties which result in an unexpected increase in the duration of this process, which entails a decrease in the economic performance of the mine.

The results of studies of underground stress conditions in longwall mines as well as the problems associated with salvage operations, are discussed in [1-7].

\section{Methods}

To study the relationship between the longwall face width and the duration of the salvage operations we used the regression and correlation analysis methods.

\footnotetext{
${ }^{*}$ Corresponding author: eia.pm@kuzstu.ru
} 


\section{Results}

The modern longwall salvage technology includes the installation of flexible mesh to protect the longwall face area from falls of roof rocks.

The procedure for the installation of the protective flexible mesh above the roof supports and along the transportation path is designed based on the mining conditions and the required width of the protective flexible mesh. The flexible mesh is made from a singlepiece high-strength plastic mesh with a length exceeding the width of the longwall face and a width of $14.0 \mathrm{~m}$. The formation of the salvage chamber begins at a distance of $14.0 \mathrm{~m}$ from the final face position. The meshing requires 12 longwall cycles (shears) at the full working thickness of the seam.

The flexible mesh is gradually installed above the canopies of the roof supports at the end of each shear. Using hand hoists, a roll of flexible mesh is unwound behind the shearer. The unwound flexible mesh is secured with face sprags to the roof at every second support and roofbolts are installed into the roof of the salvage chamber. Figure 1 shows the four stages of the installation of flexible mesh as part of each cycle.

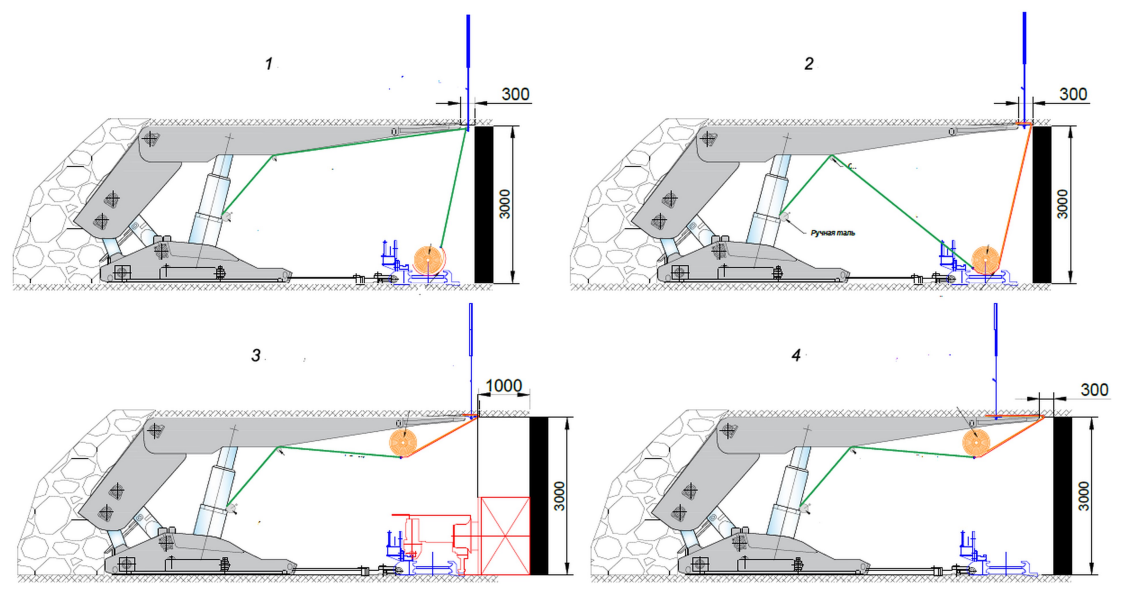

Fig. 1. Flexible mesh installation stages.

The remaining part of the plastic mesh is lowered along the longwall face and secured to the face with bolts.

In areas where roof rocks have delaminated and there is excessive stress concentration, the roof is reinforced using polyurethane resin. Polyurethane resin is pumped after the bolts have been installed, at least $10 \mathrm{~m}$ behind the area of drilling holes.

To reduce the duration of longwall salvage operations, we need to identify factors which have a negative impact on this process. In this regard, in this paper we have analyzed the salvage operations in 2011-2018 in the following JSC SUEK-Kuzbass mines: Polysaevskaya, Kirova, Taldinskaya-Zapadnaya 1, November 7th, Krasnoyarskaya (Rubana), Komsomolets, Kotinskaya (Yalevskogo).

The salvage operations are divided into two stages: 1) formation of the salvage chamber; 2) salvage of longwall face equipment (shearer, AFC, BSL, crusher) and roof supports. Table 1 shows the average annual performance of salvage operations in 20112018 in SUEK-Kuzbass mines.

Table 1. Average performance of longwall salvage operations in SUEK-Kuzbass mines, 2011-2018. 


\begin{tabular}{|c|c|c|c|c|c|c|}
\hline Year & $\begin{array}{c}\text { Number of } \\
\text { salvages }\end{array}$ & $\begin{array}{c}\text { Average } \\
\text { face width } \\
\text { (m) }\end{array}$ & $\begin{array}{c}\text { Formation of } \\
\text { salvage } \\
\text { chamber (days) }\end{array}$ & $\begin{array}{c}\text { Salvage of } \\
\text { longwall face } \\
\text { equipment } \\
\text { and roof } \\
\text { supports } \\
\text { (days) }\end{array}$ & $\begin{array}{c}\text { Total time } \\
\text { (days) }\end{array}$ & $\begin{array}{c}\text { Excessive } \\
\text { duration of } \\
\text { salvage } \\
\text { operations } \\
\text { (days) }\end{array}$ \\
\hline 2011 & 11 & 237 & 18 & 55 & 73 & 99 \\
\hline 2012 & 13 & 251 & 21 & 56 & 77 & 169 \\
\hline 2013 & 10 & 276 & 21 & 59 & 80 & 160 \\
\hline 2014 & 9 & 253 & 28 & 50 & 78 & 126 \\
\hline 2015 & 10 & 239 & 23 & 57 & 80 & 160 \\
\hline 2016 & 12 & 279 & 22 & 46 & 68 & 48 \\
\hline 2017 & 6 & 273 & 22 & 44 & 66 & 12 \\
\hline 2018 & 6 & 303 & 23 & 64 & 87 & 138 \\
\hline
\end{tabular}

In 2011-2017, the standard time for a $300 \mathrm{~m}$ face in terms of the formation of the salvage chamber was 18 days, and for the salvage of longwall face equipment and roof supports -46 days. The total standard salvage time was 64 days. Thus, within the reviewed period, the standard salvage time was exceeded.

The number of days in excess of the standard for salvage operations ranged from 12 to 169 days per year. Thus, over the past 8 years, the total number of days spent in excess of the standard for the salvage operations has exceeded 900 days.

\section{Practical application}

There has been a study of the relationship between the average longwall face width and the duration of the following operations: 1) formation of the salvage chamber; 2) salvage of AFC plus BSL and roof supports; 3) total salvage time. The graphs representing changes in these values are shown in Figure 2.

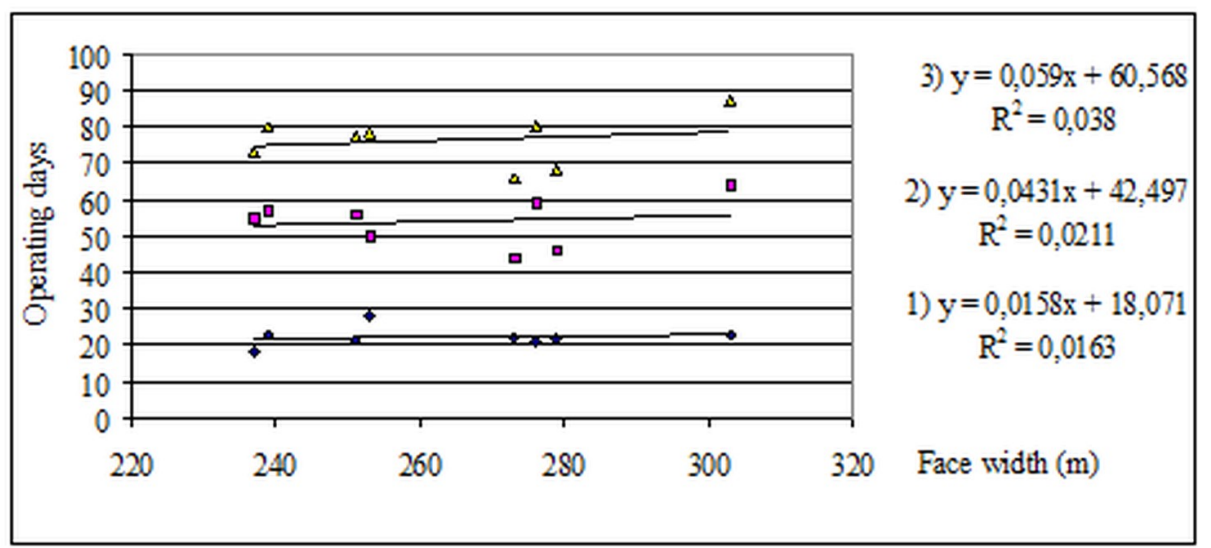

Fig. 2. Changes in the duration of: 1) formation of the salvage chamber; 2) salvage of AFC plus BSL and roof supports; 3 ) total salvage time.

Regression equations between the face width and the duration of the following operations have been derived: 1) formation of the salvage chamber; 2) salvage of AFC plus BSL and roof supports; 3) total salvage time. These equations are shown in Figure 2.

The mathematical statistics methods enable us to check whether there is a relationship between these factors. If the number of experiments is $n=8$, the critical value of $R^{2}=0.499$ 
[8]. Since the calculated values of $\mathrm{R}^{2}$ are less than the critical value, we can conclude that the longwall face width of 230 to $300 \mathrm{~m}$ has an insignificant effect on the salvage time.

The target duration of salvage operations for JSC SUEK mines for 2018-2019 is shown in Table 2.

Table 2. Target duration of salvage operations, 2018-2019.

\begin{tabular}{|c|c|c|c|c|c|c|}
\hline & \multicolumn{2}{|c|}{$\begin{array}{c}\text { Salvage chamber } \\
\text { formation }\end{array}$} & $\begin{array}{c}\text { Salvage, installation } \\
\text { and pre- } \\
\text { commissioning } \\
\text { operations }\end{array}$ & \multicolumn{2}{|c|}{ Total } \\
\cline { 2 - 7 } & 2018 & 2019 & 2018 & 2019 & 2018 & 2019 \\
\hline $\begin{array}{c}250 \mathrm{~m} \text { face, } \\
\text { seam thickness up to } 2.5 \mathrm{~m}\end{array}$ & 20 & 20 & 48 & 48 & 68 & 68 \\
\hline $\begin{array}{c}300 \mathrm{~m} \text { face, } \\
\text { seam thickness up to } 2.5 \mathrm{~m}\end{array}$ & 21 & 21 & $49(45)$ & $47(43)$ & $70(66)$ & $68(64)$ \\
\hline $\begin{array}{c}400 \mathrm{~m} \text { face, } \\
\text { seam thickness up to } 2.5 \mathrm{~m}\end{array}$ & & 26 & & $63(59)$ & & 91 \\
\hline $\begin{array}{c}300 \mathrm{~m} \text { face, } \\
\text { seam thickness over 2.5 m }\end{array}$ & 20 & 20 & $40(36)$ & $38(34)$ & $62(58)$ & $60(56)$ \\
\hline $\begin{array}{c}400 \mathrm{~m} \text { face, } \\
\text { seam thickness over 2.5 m }\end{array}$ & 25 & 25 & $59(55)$ & $57(53)$ & $84(80)$ & $82(78)$ \\
\hline
\end{tabular}

The values shown in Table 2 are to be used as a reference for the future development of SUEK-Kuzbass mines.

\section{Conclusion}

1. Analysis of the current state of salvage operations in JSC SUEK-Kuzbass mines shows that reducing the duration of longwall transfer operations is a topical problem. In the last 8 years, the total number of days in excess of the standard time for longwall face transfers exceeded 900 days.

2. The longwall face width of 230 to $300 \mathrm{~m}$ does not have any significant effect on the duration of salvage operations.

3. The effect of geological and geotechnical factors on the geomechanical condition of salvage chambers should be investigated to develop effective actions for reducing the duration of longwall face equipment salvage operations.

\section{Reference}

1. V. Zubov, G. Karpov, International Multidisciplinary Scientific GeoConference Surveying Geology and Mining Ecology Management, SGEM 14 ${ }^{\text {th }}$, 299, 12 (2014)

2. O. Kazanin, V. Klimov, V. Alekseev, A. Sidorenko, IJCIET, 10:02, 87 (2019)

3. J.A.L. Napier, D.F.Malan, International Journal of Rock Mechanics and Mining Sciences, 109, 76 (2018)

4. Syd Peng, Feng Du, Jingyi Cheng, Yang Lid, International Journal of Mining Science and Technology, 29:2, 122 (2019)

5. Jinfeng Ju, Jialin Xu, Weibing Zhu, International Journal of Rock Mechanics and Mining Sciences, 77, 55 (2015)

6. V. R. Boothukuri, M. Bhattacharjee, D. C.Panigrahi, G. Benerjee, International Journal of Mining Science and Technology, 29:2, 31 (2019)

7. T. Kim, V. Dyrdin, V. Smirnov, V. Nesterov, E3S Web of conferences, 15, 01012 (2017) 
8. D.C. Montgomery, E.A. Peck, G.G. Vining, Introduction to Linear Regression Analysis (Springer, Berlin, 2013) 